\title{
Membangun Kesadaran Masyarakat Melalui Program Kebersihan dan Penanaman Tumbuhan Pada Lingkungan Masyarakat di Sekitar Sungai Ciliwung, Kelurahan Tanjung Barat
}

\author{
Deni Nasir Ahmad \\ Fakultas MIPA, Universitas Indraprasta PGRI \\ E-mail: deninasirahmad@gmail.com

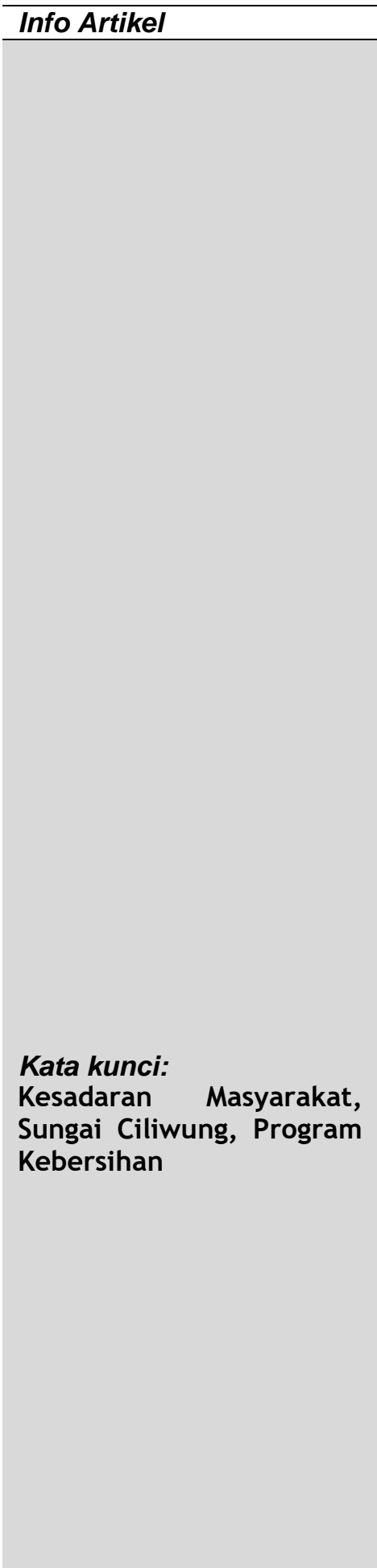 \\ Abstract \\ The purpose of community service activities is to provide \\ services to the community about the improvement of the \\ environment and instill community care about cleanliness, \\ health and prevent flooding or landslides due to erosion of land \\ on the banks of the Ciliwung river by planting landslides. The \\ method used in community service is a. Direct observation, $b$. \\ Planning activities for environmental improvement projects \\ where we divide the team with several tasks and activities, \\ namely, the first step is to clean the ciliwung river flow, the \\ second step is to plant anti-landslide plants and finally to sort \\ and process inorganic waste. c. Conduct evaluation and shering \\ together to find mutual agreement in making environmental \\ improvements. The results of community service activities \\ carried out by the service team consist of: $a$. participants were \\ given general knowledge about the types of riverbanks and were \\ given plant seeds to be planted for landslide prevention plants \\ as well as for greening around the banks of the river activities \\ carried out with the community "ngumpal" (Ngumpul Anak Lintas \\ Ciliwung). b. In community service activities the service team \\ divided 3 groups with different assignment locations and with \\ the same group assignments. c. After distributing work groups, \\ the service team carried out cleaning activities around the river \\ flow and planting trees or landslide-resistant plants. \\ Conclusions from community service activities are: $a$. The \\ community is very accepting and positively welcomed by the \\ activities that the service team has done. $b$. The community \\ began to look concerned with listening to counseling and \\ participating in all activities that the service team had designed \\ for service activities.

\footnotetext{
Abstrak

Tujuan dari kegiatan pengabdian masyarakat adalah untuk memberikan pelayanan kepada lingkungan masyarakat mengenai perbaikan lingkungan serta menanamkan kepedulian masyarakat terhadap kebersihan, kesehatan dan mencegah banjir atau longsor dengan akibat terkikisnya tanah di tepian sungai ciliwung dengan menanam tanaman anti longsor. Metode yang digunakan dalam pengabdian masyarakat adalah a. Observasi langsung, b. Melakukan kegiatan perencanaan proyek perbaikan lingkungan dimana kami membagi tim dengan beberapa tugas dan kegiatan yakni, langkah pertama membersihkan aliran sungai ciliwung, langkah kedua penanaman tanaman anti longsor dan terakhir melakukan pemilahan dan pengolahan sampah anorganik. c. Melakukan evaluasi dan shering bersama untuk menemukan kesepakatan bersama dalam melakukan perbaikan lingkungan. Hasil dari kegiatan pengabdian masyarakat yang dilakukan oleh tim pengabdi terdiri dari : a. peserta diberikan pengetahuan
} 


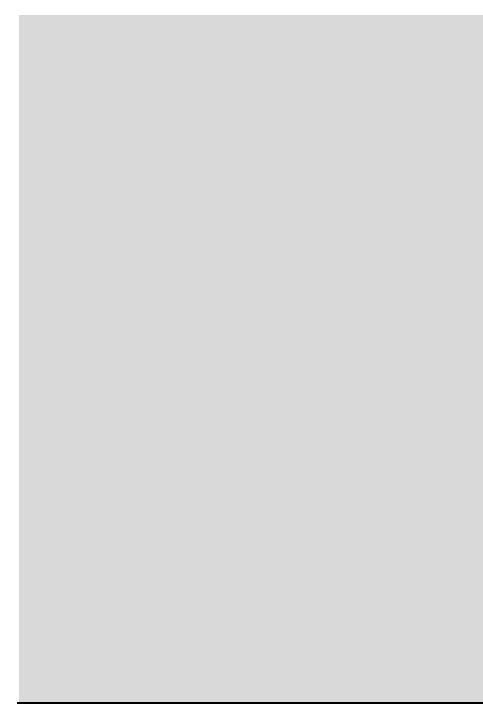

umum mengenai jenis tanaman tepian sungai dan diberikan bibit tanaman yang akan ditanam untuk tanaman pencegah longsor sekaligus untuk penghijauan sekitar tepian sungai kegiatan dilakukan bersama komunitas "ngumpal” (Ngumpul Anak Lintas Ciliwung). b. Dalam kegiatan pengabdian masyarakat tim pengabdi membagi 3 kelompok dengan lokasi tugas berbedabeda dan dengan tugas kelompok yang sama. c. Setelah membagikan kelompok kerja maka tim pengabdi melakukan kegiatan membersihkan sekitar aliran sungai dan kegiatan penanaman pohon atau tanaman tahan longsor. Simpulan dari kegiatan pengabdian masyarakat yaitu : a. Masyarakat sangat menerima dan menyambut secara positif dari kegiatan yang tim pengabdi telah lakukan. b. Masyarakat mulai terlihat peduli dengan mau mendengar penyuluhan dan mengikuti seluruh kegiatan yang telah tim pengabdi rancang untuk kegiatan pengabdian.

\section{PENDAHULUAN}

Lingkungan sehat dan bersih agar tetap terawat dan terjaga merupakan tanggung jawab secara bersama. Namun permasalahan yang terjadi pada lingkungan banyaknya masyarakat tidak adanya kepedulian terhadap lingkungan terutama pada deretan aliran sungai. Banyaknya sampah yang menumpuk di sekitar aliran sungai mengakibatkan wilayah sungai menjadi tercemar ditambah lagi adanya bangunan diatas permukaan sungai yang memperparah keadaan dan kondisi sungai. Menyebabkan kondisi sungai aliran airnya tidak mengalir, tercemar dan bisa terjadi banjir kepermukaan. Akibat dari banjir yang disebabkan aliran air sungai tidak mengalir seperti penyakit kulit, diare, pes dan lain-lain. Agar dapat mengukur dampak dari pembuangan zat-zat pencemaran polutan, maka digunakanlah parameter-parameter polutan seperti BOD, padatan tersuspensi, COD, berbagai senyawa logam maupun kimiawi beracun seperti senyawa-senyawa organik halogen dan petroleum hidrokarbon. Zat-zat ini apabila memasuki air permukaan dan air tanah akan mendegradasikan kualitas yang terkandung dalam air tersebut. Degradasi kualitas ini dapat berkisar dari bau-bau yang busuk membahayakan kehidupan air dan bahkan menyebabkan air menjadi berbahaya bagi kehidupan manusia. Adapun permasalahan yang terjadi pada wilayah pengabdian masyarakat adalah sebagai berikut :

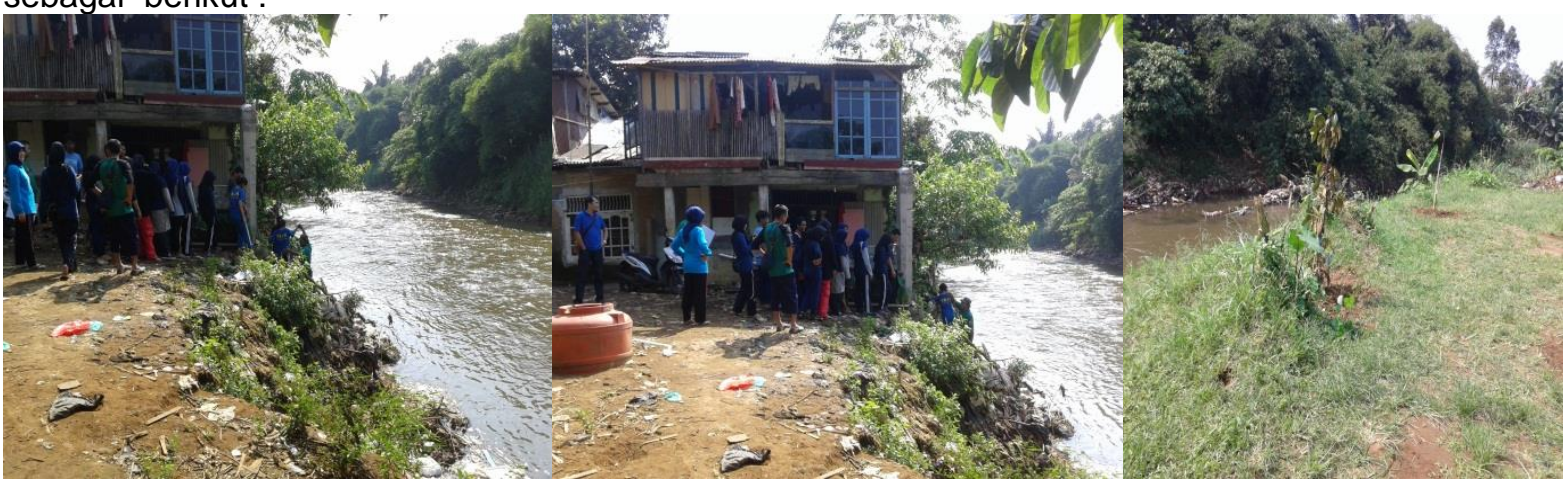

\section{Gambar 1 \\ Tempat Pengabdian Masyarakat dan Permasalahannya}

Dari gambar tersebut terlihat terjadinya permasalahan seperti pencemaran dan adanya wilayah yang kemungkinan terjadinya pengikisan lahan permukaan di deretan aliran sungai. Menurut 
Undang-undang Nomor 32 Tahun $2009^{1}$ Pencemaran lingkungan hidup adalah masuk atau dimasukkannya makhluk hidup, zat, energi, dan/atau komponen lain ke dalam lingkungan hidup oleh kegiatan manusia sehingga melampaui baku mutu lingkungan hidup yang telah ditetapkan. Terdapat beberapa cara utama polutan memasuki air permukaan, diantaranya melalui : a) Pembuangan langsung dari limbah industri maupun rumah tangga. b) Masukkan tidak langsung melalui perembesan air tanah atau "leaching". c) Masukkan melalui penyebaran udara (airborne dispersal) atau deposito atmosfir. d) Masukkan karena dibuang begitu saja (dumping) dan karena kecelakaan². Pencemaran yang sering terjadi pada wilayah sungai disebabkan oleh :

\section{a. Pencemaran dari pertanian}

Limbah dari pertanian yang masuk ke dalam air sebenarnya tidak berbahaya bagi keberlangsungan ekosistem air namun karena saat ini banyak petani menggunakan pupuk kimia dan juga pestisida dalam jumlah banyak maka mampu mengakibatkan kerusakan pada ekosistem yang ada. Hal ini akan lebih parah jika pestisida yang digunakan adalah jenis dari herbisida dan insektisida.

b. Pencemaran dari Peternakan dan Perikanan

Air dapat mengalami pencemaran dari kegiatan peternakan dan perikanan jika tidak dilakukan pembuangan yang benar pada kotoran hewan dan juga sampah lainnya, ada beberapa hal yang bisa dilihat untuk melihat ciri-ciri dari terjadinya pencemaran oleh peternakan dan perikanan ini antara lain adalah sebagai berikut : Adanya kotoran hewan dalam jumlah besar pada perairan yang membuat air terkontaminasi oleh berbagai virus dan bakteri dari kotoran tersebut dan terjadinya perubahan warna dan rasa di dalam air tersebut sehingga membuat air sangat mudah menyebabkan penyakit bagi siapa saja yang mengkonsumsi.

c. Pencemaran dari Industri

Para pelaku industri sangat rawan menghasilkan berbagai jenis limbah yang dapat mencemari air. Ini biasanya dilakukan oleh mereka para pelaku bisnis industri yang kurang memahami adanya pencemaran ini atau hanya sekedar untuk menekan biaya pengolahan limbahnya saja. berikut ini beberapa jenis industri yang mampu mencemari air dari hasil industrinya :

1. Industri produk makanan

2. Indukstri produk tekstil

3. Industri pulp dan kertas

4. Industri bahan kimia

5. Industri penyamakan kulit

6. Industri electroplating

d. Pencemaran dari Aktivitas Perkotaan

Daerah perkotaan menjadi salah satu tempat yang rawan terjadi pencemaran air. Hal ini tidak jauh dari jumlah populasi penduduk yang kian pesat sedangkan lahan tetap sehingga menyebabkan munculnya berbagai pemukiman padat penduduk dengan sanitasi yang tidak memadai. Pencemaran air di perkotaan juga bisa disebabkan karena hasil dari pabrik, limbah rumah tangga, kotoran manusia, limbah cair dan lainnya ${ }^{3}$.

Dampak pencemaran air pada umumnya dibagi atas 4 kelompok, yaitu :

1. Dampak terhadap kehidupan biota air

- Banyaknya zat pencemaran pada air limbah akan menyebabkan menurunnya kadar oksigen terlarut dalam air tersebut. Sehingga mengakibatkan kehidupan dalam air membutuhkan oksigen terganggu serta mengurangi perkembangannya.

1 Undang-undang Republik Indonesia Nomor 32 Tahun 2009, Tentang Perlindungan Dan Pengelolaan Lingkungan Hidup,

2 Wahyu Wibowo. Dampak Pemanfaatan Lahan Terhadap Kualitas Air Permukaan Dan Air Tanah. 3 Oktober 2003. www. jurnal.upi.edu

${ }^{3}$ Maya Sari, 5 Mei 2018. Pencemaran Air : Pengertian, Sumber, Jenis dan Akibat. https://ilmugeografi.com 
- Akibat matinya bakteri-bakteri, maka proses penjernihan air secara alamiah yang seharusnya terjadi pada air limbah juga terhambat. Dengan air limbah yang sulit terurai. Panas dari industri juga akan membawa dampak bagi kematian organisme, apabila air limbah tidak didinginkan terlebih dahulu.

2. Dampak terhadap kualitas air tanah

Pencemaran air tanah oleh tinja yang biasa diukur dengan faecal coliform telah terjadi dalam skala yang luas, hal ini dibuktikan oleh suatu survey sumur dangkal di Jakarta. Banyak penelitian yang mengindikasikan terjadinya pencemaran tersebut.

3. Dampak terhadap kesehatan

Peran air sebagai pembawa penyakit menular bermacam-macam antara lain :

- Air sebagai media untuk hidup mikroba pathogen,

- Air sebagai sarang insekta penyebar penyakit,

- Jumlah air yang tersedia tidak cukup, sehingga manusia bersangkutan tak dapat membersihkan diri,

- Air sebaga media untuk hidup vector penyakit.

4. Dampak terhadap estetika lingkungan

Dengan semakin banyaknya zat organik yang dibuang kelingkungan perairan, maka perairan tersebut akan semakin tercemar yang biasanya ditandai dengan bau yang menyengat disamping tumpukan yang dapat mengurangi estetika lingkungan. Masalah limbah minyak atau lemak juga dapat mengurangi estetika lingkungan ${ }^{4}$.

Dari pencemaran dan bahan penyebab pencemaran tersebut mengakibatkan adanya pengikisan wilayah menyebabkan mudahnya terjadinya longsong permukaan tanah dan kualitas nutrisi atau zat hara pada tanah menurun dan kandungan air tanah menjadi tercemar. Oleh sebab itu diperlukan pohon penyangga sungai. Dari hasil penelitian Ramdan ${ }^{5}$ adalah sebagai berikut: 1 . Pada bagian hulu DAS Ciliwung jenis tumbuhan pencegah erosi ditemukan sebanyak 19 jenis dari 12 suku. Jenis yang mendominasi adalah Panicum maximum dengan INP sebesar $41,83 \%$. Tingkat keanekaragaman jenis dikategorikan rendah dengan nilai $\mathrm{H}^{\prime}$ sebesar 0,95. 2. Pada bagian tengah DAS Ciliwung jenis tumbuhan pencegah erosi ditemukan sebanyak 15 jenis dari 9 suku. Jenis yang mendominasi adalah Pennisetum purpureum dengan INP sebesar $44,16 \%$. Tingkat keanekaragaman jenis dikategorikan rendah dengan nilai H' sebesar 0,90. 3. Persentase jenis tumbuhan pencegah erosi bagian hulu DAS Ciliwung adalah $57,5 \%$ dan bagian tengah DAS Ciliwung adalah $45,4 \%$. Menurut budiawati ${ }^{6}$, tanaman penutup tanah mempunyai peranan: (1) menahan atau mengurangi daya perusak butir-butir hujan yang jatuh dan aliran air di atas permukaan tanah, (2) menambah bahan organik tanah melalui batang, ranting dan daun mati yang jatuh, dan (3) menyerap air dan melakukan transpirasi.

Oleh karenanya peranan tumbuhan atau pohon berada pada sekitar tepi sungai berdasarkan pendapat tersebut salah satunya yakni berperan dalam pencegah banjir atau menahan daya perusak butir-butir hujan yang jatuh dan aliran air di atas permukaan tanah. Tumbuhan atau pepohonan dapat dipergunakan dalam penghijauan sungai, ada beberapa macam jenis tanaman yang cocok sebagai tanaman vegetasi sungai diantaranya : a. Jenis Tumbuhan Bambu. Menurut Lembaga Ilmu Pengetahuan Indonesia (LIPI) menilai bambu merupakan salah satu tanaman yang cocok untuk memperbaiki kondisi hulu serta sempadan sungai yang saat ini telah banyak mengalami kerusakan akibat banjir bandang dan tanah longsor ${ }^{7}$. b. Bungur (Lagerstroemia). Merupakan tumbuhan

4 Carlos. Penyebab, Dampak dan Pengendalian Pencemaran Air. 2 Desember 2016. http://www.bengkulunews.co.id

${ }^{5}$ Herdi Ramdhan. dkk. Keanekaragaman Jenis Tumbuhan Pencegah Erosi Di Daerah Aliran Sungai (DAS)

Ciliwung. 5 Juni 2018, www.perpustakaan.fmipa.unpak.ac.id

6 Budiwati. Tanaman Penutup Tanah Untuk Mencegah Erosi. Majalah WUNY XVI Nomor 2, Mei 2014. https://journal.uny.ac.id

7 Richard Andika. LIPI: Tanaman Bambu Bisa Cegah Banjir Bandang dan Longsor. 23 November 2016. www.tempo.com 
berwujud pohon atau perdu yang dikenal sebagai pohon peneduh jalan atau pekarangan. Mampu hidup ditanah gersang atau subur. Bungur mampu hidup diketinggian 800 mdpl serta digunakan sebagai pohon penghijauan. b. Pohon Dadap. Dadap merupakan Pohon yang berukuran sedang, mencapai tinggi 15-20 m dan gemang $50-60 \mathrm{~cm}$. Bagian kulit batang yang masih muda dan halus bergaris-garis vertikal hijau, abu-abu, coklat muda atau keputihan; batang biasanya dengan duri-duri tempel kecil (1-2 $\mathrm{mm}$ ) yang berwarna hitam. Tajuknya atau membulat renggang, menggugurkan daun di musim kemarau. Dadap kerap dipakai sebagai pohon peneduh di kebun-kebun kopi dan kakao, atau pohon rambatan bagi tanaman lada, sirih, panili, atau umbi gadung. Juga baik digunakan sebagai tiang-tiang pagar hidup. Di wilayah Pasifik, dadap dimanfaatkan sebagai penahan angin. c. Johar. Johar atau juar adalah nama sejenis pohon penghasil kayu keras yang termasuk suku Fabaceae (=Leguminosae, polong-polongan). Daunnya menyirip genap, $10-35 \mathrm{~cm}$ panjangnya; dengan tangkai bulat torak sepanjang $1,5-3,5 \mathrm{~cm}$ yang beralur dangkal ditengah poros tanpa kelenjar. Johar juga sering ditanam dalam sistem pertamanan campuran (agroforestri ). Perakarannya yang luas mampu menahan air secara baik .

Dari permasalahan tersebut perlu adanya tindakan langkah perventif dan perbaikan agar lingkungan disekitar sungai menjadi bersih dan tidak tercemar. Sehingga air sungai dapat kembali dimanfaatkan sebagai wisata dan wahana edukasi bagi masyarakat. Disinilah perlu adanya keperduliaan masyarakat disekitar sungai agar menjaga dan merawat daerah aliran sungai. Oleh karenanya program kegiatan kami dalam melakukan perbaikan dan keperdulian lingkungan bersama tim pengabdi yang terdiri dari dosen, mahasiswa pendidikan matematika semester 4 tahun ajaran 2017/2018 dan organisasi kemasyarakatan yakni "ngumpal" (Ngumpul Anak Lintas Ciliwung) kelurahan Tanjung Barat, kegiatannya berupa melakukan usaha perbaikan dengan mengajak masyarakat disekitar aliran sungai untuk melakukan perubahan terhadap sungai yang berada diwilayah sekitar tempat tinggal masyarakat di kelurahan Tanjung Barat khususnya masyarakat sekitar bantaran sungai ciliwung.

\section{RUMUSAN MASALAH}

Dari latar Belakang yang telah dijabarkan dapat dibuat rumusan masalah sebagai berikut : a. Apakah dengan adanya kegiatan yang dilakukan dapat menimbulkan antusias masyarakat di sekitar bantaran sungai untuk mau berbuat merubah lingkungan hidup tempat tinggalnya atau tetap akan terus merusak lingkungan. b. apakah dengan ditanami tumbuhan anti longsor masyarakat mau peduli menjaga dan melestarikan lingkungan ataukah akan merusak kembali habitat tumbuhan dan hewan sekitar sungai.

\section{METODE}

Dalam melakukan kegiatan pengabdian masyarakat tim pengabdi melakukan metode kegiatan sebagai berikut :

1. Observasi langsung yakni pangabdi langsung datang ke lokasi pengabdian untuk memperolah data. Hal ini kami lakukan pada saat menjelang maupun saat kegiatan berlangsung. Observasi berguna untuk mengetahui kondisi permasalahan yang ada dan sumber daya yang dapat dimanfaatkan dalam melakukan kegiatan.

2. Melakukan kegiatan perencanaan proyek perbaikan lingkungan dimana kami membagi tim dengan beberapa tugas dan kegiatan yakni, langkah pertama membersihkan aliran sungai ciliwung, langkah kedua penanaman tanaman anti longsor dan terakhir melakukan pemilahan dan pengolahan sampah anorganik.

3. Melakukan evaluasi dan shering bersama untuk menemukan kesepakatan bersama dalam melakukan perbaikan lingkungan.

\section{PEMBAHASAN}

Kegiatan pengabdian ini dilaksanakan pada hari Sabtu, 7 Juli 2018 di sekitar tepian sungai kali ciliwung dari belakang kantor kejaksaan Jakarta Selatan Kecamatan Jagakarsa sampai dengan jembatan perbatasan Kecamatan Jagakarsa dengan Kecamatan Pasar Rebo. Diikuti 60 orang peserta yang terdiri dari warga sekitar tepian sungai kali ciliwung, kelompok masyarakat pecinta kali ciliwung (ngumpal) dan mahasiswa, kegiatan dilaksanakan dari pukul 08.00 s.d. 13.00 WIB. Kegiatan ini 
merupakan upaya tim pengabdi untuk memberikan pelayanan kepada lingkungan masyarakat mengenai perbaikan lingkungan serta menanamkan kepedulian masyarakat terhadap kebersihan, kesehatan dan mencegah banjir atau longsor akibat terkikisnya tanah di tepian sungai ciliwung. Kegiatan dilakukan dengan cara mengumpulkan masyarakat kemudian tim pengabdi melakukan kegiatan penyuluhan mengenai pentingnya menjaga lingkungan sungai dan dampak terhadap masyarakat serta lingkungan sekitar, setelah melakukan pengarahan dan penyuluhan tim pengabdi bersama dengan masyarakat serta kelompok masyarakat pecinta sungai ciliwung (ngumpal) melakukan kegiatan penanaman tanaman tahan longsor dan membersihkan lingkungan ditepian sungai ciliwung. Kegiatan ini dilakukan guna mengurangi sampah disekitar tepian sungai ciluwung, penghijauan dan melakukan edukasi kepada masyarakat mengenai pentingnya melakukan perbaikan sungai terutama di tepian sungai ciliwung.

Adapun kegiatan pengabdian masyarakat adalah sebagai berikut : a. peserta diberikan pengetahuan umum mengenai jenis tanaman tepian sungai dan diberikan bibit tanaman yang akan ditanam untuk tanaman pencegah longsor sekaligus untuk penghijauan sekitar tepian sungai kegiatan dilakukan bersama komunitas "ngumpal" (Ngumpul Anak Lintas Ciliwung).
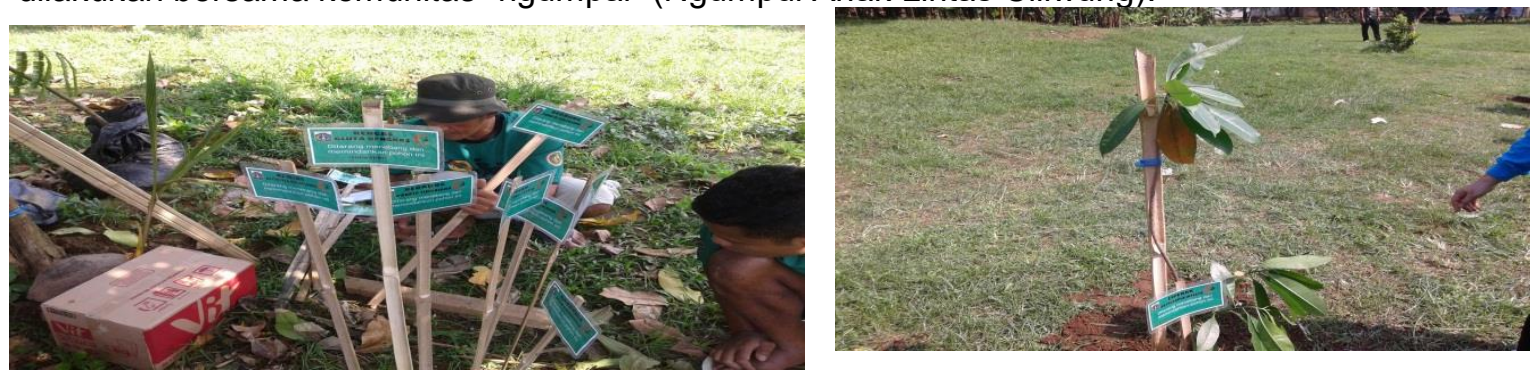

Gambar 2.

Pemberian Nama dan Bibit Tanaman Bekerjasama dengan Kumunitas "Ngumpal”

b. Dalam kegiatan pengabdian masyarakat tim pengabdi membagi 3 kelompok dengan lokasi tugas berbeda-beda dan dengan tugas kelompok yang sama yakni melakukan pembersihan dan penanaman tumbuhan tahan longsor di tepian sungai ciliwung dari sekitar wilayah Kejaksaan, Tanjung Barat, Jakarta Selatan sampai dengan perbatasan jembatan kecamatan Jagakarsa, Jakarta Selatan dengan Kecamatan Pasar Rebo, Jakarta Timur.
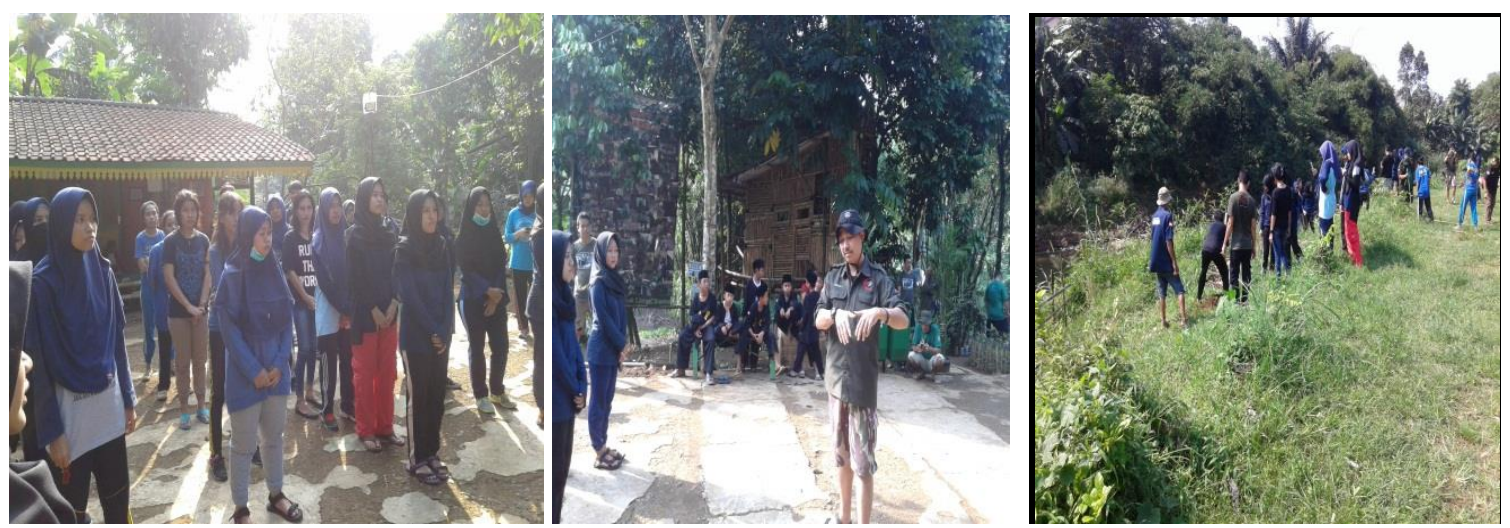

Gambar 3.

Pembagian Kelompok Kerja 
c. Setelah membagikan kelompok kerja maka tim pengabdi melakukan kegiatan membersihkan sekitar aliran sungai dan kegiatan penanaman pohon atau tanaman tahan longsor.
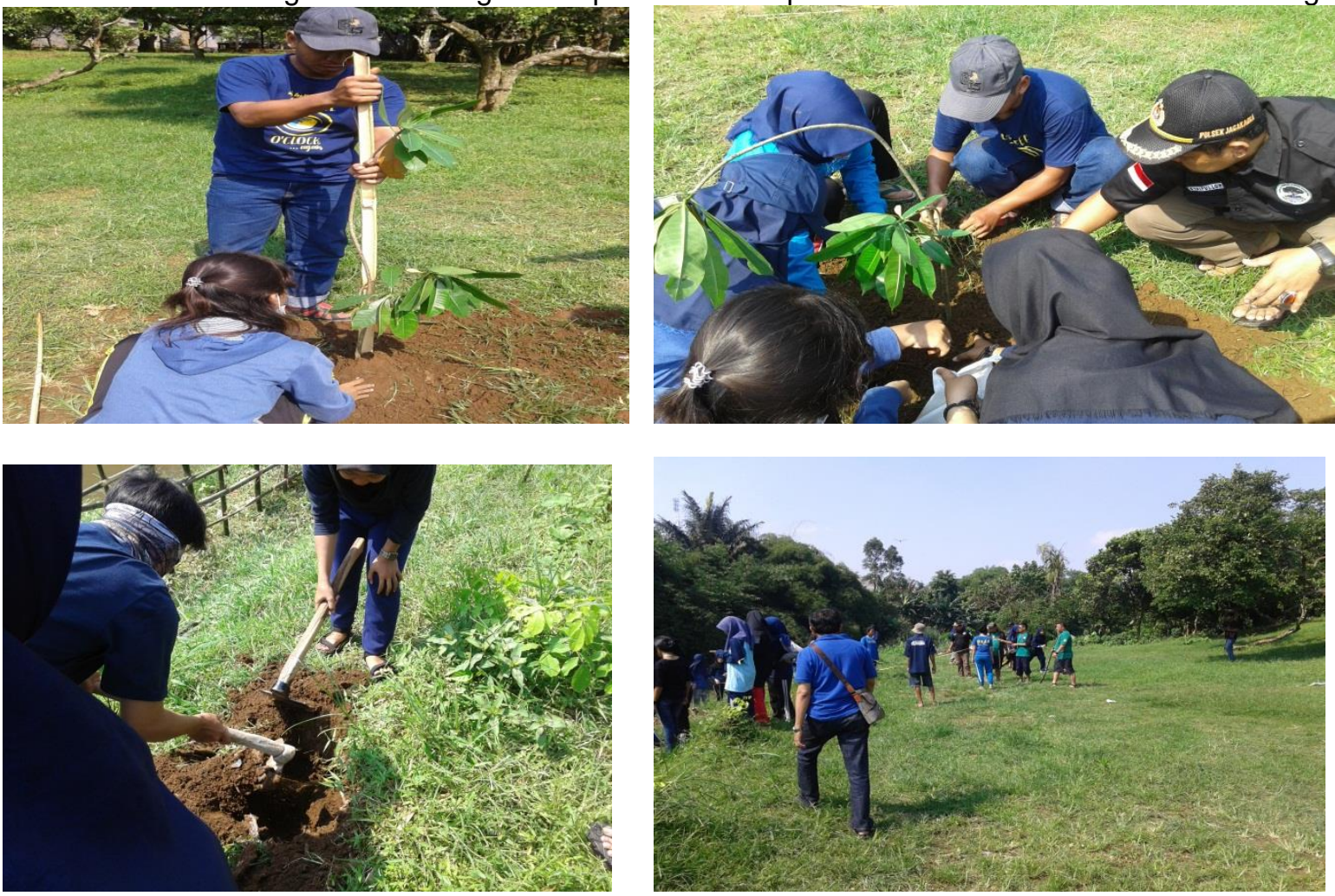

\section{Gambar 4. \\ Kegiatan Penanaman dan Kebersihan Lahan Sekitar Bantaran Sungai Ciliwung}

\section{PENUTUP}

Dari kegiatan pengabdian masyarakat ini maka dapat disimpulkan sebagai berikut :

1. Masyarakat sangat menerima dan menyambut secara positif dari kegiatan yang tim pengabdi telah lakukan.

2. Masyarakat mulai terlihat peduli dengan mau mendengar penyuluhan dan mengikuti seluruh kegiatan yang telah tim pengabdi rancang untuk kegiatan pengabdian.

\section{REFERENCES}

Undang-undang Republik Indonesia Nomor 32 Tahun 2009 Tentang Perlindungan Dan Pengelolaan Lingkungan Hidup

Budiwati. Tanaman Penutup Tanah Untuk Mencegah Erosi. Majalah WUNY XVI Nomor 2, Mei 2014. https://journal.uny.ac.id

Ramdhan, Herdi. Dkk. Keanekaragaman Jenis Tumbuhan Pencegah Erosi Di Daerah Aliran Sungai (DAS) Ciliwung. https://.perpustakaan.fmipa.unpak.ac.id

Wibowo, Wahyu. Dampak Pemanfaatan Lahan Terhadap Kualitas Air Permukaan Dan Air Tanah. https://. jurnal.upi.edu

Andhika, Richard. LIPI: Tanaman Bambu Bisa Cegah Banjir Bandang dan Longsor. 23 November 2016. https://tempo.co.id

Baihaqi, Ahmad. Ara, Pohon Pinggiran Sungai yang Banyak Manfaat. 17 Mei 2018. http://www.greeners.com

Dunia Pendidikan Manfaat Sungai dan Macam-macamnya 5 June http://www.berpendidikan.com

Karim, Abdul. 20 Tanaman yang cocok untuk penghijauan. 12 April 2014. http://diarykarim.blogspot.co.id 
Pusat IImu Geografi Indonesia. 20 Jenis-jenis Sungai di Indonesia. 5 Juni 2017. https://ilmugeografi.com

Sari, Maya. Pencemaran Air : Pengertian, Sumber, Jenis dan Akibat. 5 Mei 2018. https://ilmugeografi.com

Toruan, Lumban Holmes Carlos. Penyebab, Dampak dan Pengendalian Pencemaran Air. 2 Des 2016. http://www.bengkulunews.co.id 